\title{
Pengaruh Komposisi Media Tanam dan Konsentrasi Giberelin terhadap Pertumbuhan dan Hasil Bunga Mawar (Rosa hybrida $\mathbf{L}$.) \\ Effect of Growing Media Compotition and Gibberellin Concentration on the Growth and Yield of Rose Plant (Rosa hybrida L.)
}

\author{
Mutiara Laudry Shita ${ }^{1}$, Rita Hayati ${ }^{1}$, Erita Hayati ${ }^{1 *}$ \\ ${ }^{1}$ Jurusan Agroteknologi, Fakultas Pertanian, Universitas SyiahKuala \\ *Corresponding author: ritahayatiagt@ gmail.com
}

\begin{abstract}
Abstrak. Tujuan dari penelitian ini ialah untuk mengetahui pengaruh komposisi media tanam dan konsentrasi giberelin serta ada tidaknya interaksi keduanaya terhadap pertumbuhan dan hasil bunga mawar (Rosa hybrida L.). Telah dilaksanakan penelitian di Dusun Sumber Rejo, Desa Sei Bamban Kecamatan Batang Serangan Nomor 25, Langkat - Sumatera Utara pada bulan April hingga Agustus 2019. Analisis data yang digunakan dalam penelitian ini adalah Rancangan Acak Kelompok (RAK) pola faktorial 4 x 3 dengan 3 ulangan. Faktor pertama yang diteliti adalah komposisi media tanam (M) yang terdiri dari 4 taraf yaitu : $\mathrm{M}_{0}$ (tanah), $\mathrm{M}_{1}$ (tanah + pupuk kandang (1:1)), $\mathrm{M}_{2}(\operatorname{tanah}+\operatorname{sekam}(1: 1)), \mathrm{M}_{3}$ (tanah + pupuk kandang + sekam (1:1:1)) dan faktor kedua adalah konsentrasi giberelin yang terdiri dari 3 taraf yaitu : $\mathrm{G}_{0}(0 \mathrm{ppm}), \mathrm{G}_{1}(200$ ppm), $\mathrm{G}_{2}(400 \mathrm{ppm}$ ) dan dilanjutkan dengan uji Beda Nyata Terkecil (BNT) pada taraf 5\%. Hasil penelitian ini adalah media tanam berpengaruh nyata terhadap jumlah cabang umur 30 HST. Komposisi terbaik dijumpai pada perlakuan media tanah+pupuk kandang+sekam. Giberelin berpengaruh sangat nyata terhadap panjang cabang umur $30 \mathrm{HST}$, berpengaruh nyata terhadap jumlah cabang umur 30, 60 dan $90 \mathrm{HST}$, dan jumlah helai bunga. Konsentrasi terbaik untuk pertumbuhan mawar dijumpai pada konsentrasi giberelin 400 ppm. Terdapat interaksi yang nyata pada kombinasi perlakuan komposisi media tanam tanah + sekam dengan pemberian konsentrasi 200 ppm terhadap diameter bunga tanaman mawar.
\end{abstract}

Kata Kunci: Mawar, Komposisi Media Tanam, Konsentrasi Giberelin.

\begin{abstract}
This research aims to find out the influence of the growing media composition and gibbberelline concentration, and their interaction on the growth and yield of rose flower (Rosa hybrida L.). This research had been held at Sumber Rejo village, Sei Bamban, Batang Serangan number 25, Langkat - North Sumatera from March to August 2019. The design used in this study was factorial block randomized with $4 \times 3$ factorial pattern and three replications. Design are two factors studied, the first factor is the composition of the planting media (M) which consists of four levels, there were : $M_{0}$ (soil), $M_{1}$ (soil + manure (1:1)), $M_{2}$ (soil + rice husk (1:1)), $\mathbf{M}_{3}$ (soil + manure + rice husk (1:1:1)) and the second factor is concentration of gibberellin that was consist of three levels, that were : $\mathrm{G}_{0}(0 \mathrm{ppm}), \mathrm{G}_{1}(200 \mathrm{ppm}), \mathrm{G}_{2}(400 \mathrm{ppm})$ and continued with Low Significant Different (LSD) at 5\% level. The results of the study shows that the growing media affect significantly the number of branches at the age of 30 DAP. The best composition of the planting media was found in the treatment of soil media + manure + rice husk. Gibberelline concentration affected significantly of the number of branches at the age of 30,60 and 90 DAP, length of the branches at $30 \mathrm{DAP}$ and the number of flowers. The best concentration for the growth of Rose is $400 \mathrm{ppm}$ an gibberelline concentration. There was interaction strands between the composition of growing media and gibberlline concentration on the diameter of flower on the rose plant on the combination treatment of composition of the soil + rice husk media by giving concentration of $200 \mathrm{ppm}$.
\end{abstract}

Keywords: Rose, The composition of growing media, Gibberelline concentration.

\section{PENDAHULUAN}

Mawar (Rosa sp.) menururt Dole dan Wilkins (2005) merupakan salah satu bunga yang paling terkenal dan paling banyak diminati di dunia. Manfaat mawar ialah sebagai tanaman pot, tanaman perkarangan, pesta pernikahan, serta sebagai bahan baku obat- 
obatan, minyak wangi dan kosmetik (Supriadi et al.,2008) sedangkan menurut Marlina dan Rohayati (2009) kegunaan mawar ialah sebagai bunga potong, mawar tanam, mawar tabur dan mawar bahan kosmetik.

Produksi mawar di Indonesia terus mengalami peningkatan dari 68.671 .463 ton pada tahun 2012 menjadi 184.455 .598 ton pada tahun 2017. Perbaikan budidaya seperti media tanam dapat meningkatan produksi dan mutu mawar. Media tanam yang akan digunakan harus sesuai dengan jenis tanaman yang akan ditanam (Zulkarnaen, 2006). Wiryanta (2007) menyatakan bahwa media tanam yang digunakan untuk memenuhi kebutuhan dan perkembangan bunga mawar antara lain dengan menggunakan campuran dari berbagai media seperti tanah, sekam padi, pupuk kandang dan serutan kayu. Rukmana (1995) menyarankan penggunaan campuran tanah, pupuk organik dan pasir dengan perbandingan 1:1:1 sebagai media tanam. Menururt Sulistyaningsih et al. (2007)penggunaan campuran media tanam tanah, pupuk kandang dan sekam (1:1:1) berpengaruh terhadap jumlah rumpun, jumlah kuntum, panjang tangkai bunga,panjang daun dan pertambahan jumlah daun pada tanaman sedap malam.

Selain dengan penggunaan media tanam, penggunaann zat pengatur tumbuh juga dapat meningkatkan pertumbuhan dan pembungaan tanaman. Zatn pengatur tumbuh "ZPT" untuk mempercepat pertumbuhan dsn meningkatkan ukuran bunga adalah asam giberelin. Santoso (2001) menyatakan bahwa giberelin dapat mematahkan dormansi (hambatan pertmubuhan tanaman) sehingga dapat memacu perkecambahan biji, pemanjangan sel, meningkatkan pembungaan tanaman serta tanaman dapat tumbuh normal. Menurut Campbell et al. (2003) giberelin adalah hormon yang dapat mempercepat perkecambahan biji, kuncup tunas, pemanjangan batang, pertumbuhan daun, merangsang pembungaan, perkembangan buah, memengaruhi pertumbuhan dan diferensiasi akar. Endah (2001) menyatakan bahwa giberelinmerupakan senyawa yang mempengaruhi proses pembelahan sel "cell division", pemanjangan sel atau keduanya.

Salah satu jenis giberelin yang stabil dan mampu memacu pertumbuhan dan pembungaan tanaman menurut Budiarto dan Wuryaningsih (2007) adalah $\mathrm{GA}_{3}$. Giberelin jenis $\mathrm{GA}_{3}$ dapat mempengaruhi pertumbuhan dan pembungaan tanaman (Budiarto, 2007). Tanaman yang diberikan giberelin umumnya memberikan respon pemanjangan batang dan pembelahan sel. Penelitian yang telahdilakuakan Sumanasiri et al. (2013) menunjukkan bahwa pemberian $\mathrm{GA}_{3}$ dapat meningkatkan panjang tangkai bunga, tinggi tanaman, dan panjang tangkai daun pada Henckelia humboldtianus.

Berdasarkan uraian di atas,perlu dilakukan penelitian untuk meningkatan produksi dan hasil bunga mawar yang dilakuakan dengan cara penggunaan komposisi media tanam dan zat pengatur tumbuh.

\section{METODEPENELITIAN}

Penelitian ini telah dilaksanakan di Langkat - Sumatera Utara pada bulan April hingga Agustus 2019. 


\section{Alat}

Alat yang digunakan yaitu gunting, penggaris, gelas ukur, handsprayer, gembor, timbangan analitik, jangka sorong, kamera digital Sony DSC-W810, software imagej "Image Processing and Analysis in Java", software Adobe Photoshop $\mathrm{CS}_{3}$ dan alat tulis.

\section{Bahan}

Bahan yang digunakan adalah bibit mawar yang digunakan adalah bibit hasil setek mawar Holland berwarna merah (sexy red), berumur 1,5 bulan sebanyak 108 tanaman. Bibit diperoleh dari produsen bibit mawar di Jl. Madirsan Ujung, Desa Bangun Sari Baru, Medan, Sumatera Utara, polibag berwarna hitam dengan ukuran $25 \mathrm{~cm}$ x $20 \mathrm{~cm}$ sebanyak 108 lembar, media tanam yang digunakan adalah tanah, pupuk kandang, dan sekam padi yang diperoleh dari tempat penggilingan padi di Langkat, Stabat, Sumatera Utara, giberelin digunakan adalah $\mathrm{GA}_{3}$ Gibgro $20 T B$ dalam bentuk tablet dengan kandungan bahan aktif Giberelic Acid 20\% dan berat dalam 1 tablet adalah 5 gram, pupuk NPK Growmore Bunga (10:55:10) dan pupuk NPK Growmore Daun (32-10-10) $2 \mathrm{~g} \mathrm{~L}^{-1}$, insektisida Decis 25 EC $0,75 \mathrm{ml} \mathrm{L}^{-1}$, dan fungisida Dithane M-45 $2 \mathrm{~g} \mathrm{~L}^{-1}$.

\section{Analisis Data}

Analisis data yang digunakan adalah Rancangan Acak Kelompok pola faktorial $4 \mathrm{x}$ 3 dengan 3 ulangan yang rerdiri dari 2 factor yaitu : faktor komposisi media tanam (M) terdiri dari 4 taraf yaitu : $\mathbf{M}_{0}$ (Tanah), $\mathbf{M}_{1}$ (Tanah + pupuk kandang 1:1), $\mathbf{M}_{2}$ (Tanah +sekam 1:1), $\mathbf{M}_{3}$ (Tanah + pupuk kandang + sekam 1:1:1). Factor konsentrasi giberelin (G) trdiri dari 3 taraf yaitu : $\mathrm{G}_{0}(0 \mathrm{ppm}), \mathrm{G}_{1}(200 \mathrm{ppm}), \mathrm{G}_{2}(400 \mathrm{ppm})$. Dari kedua factor tersebut terdapat 12 kombinasip perlakuan. Masing-masing perlakuan terdiri dari 3 polybag dan diulang sebanyak 3 kali, sehingga jumlah keseluruhan meliputi 108 polibag.

\section{Pelaksanaan Pnelitian}

\section{Persiapan media tanam}

Media tanam dibuat sesuai dengan perlakuan percobaan dengan menggunakan satuan ukuran berupa volume sebagai perbandingan. Campuran masing-masing media tanam yang telah dibuat secara merata kemudian dimasukkan kedalam polybag. Polibag yang telah terisi kemudian disusun di lapangan sesuai dengan bagan percobaan.

\section{Persiapan bibit dan penanaman}

Bibit mawar ysng digunakan adalah bibit setek yang berumur 1,5 bulan sebanyak 108 bibit. Bibit mawar dikeluarkan secara perlahan dari media sebelumnya, kemudian bibit mawar selanjutnya ditanam bersama medianya kedalam media tanam yng telah disiapkan sesuai dengan perlakuan.

\section{Pemangkasan}

Pemangkasan dilakukan pada umur 1 MST dengan memangkas cabang-cabang yang ada dan meninggalkan 1 batang utama. 


\section{Pemupukan}

Pemupukan dilakukan dengan memberikan pupuk NPK Growmore pada umur 2, 4 dan 6 MST degan konsentrasi $2 \mathrm{~g} \mathrm{~L}^{-1}$. Pemberian pupuk dilakukan dengan cara disemprot kebagian daun dan media.

\section{Pemberian giberelin}

Pembuatan larutan pekat giberelin dilakukan dengan cara melarutkan tablet giberelin kedalam $1000 \mathrm{ml}$ air sesuai dengan konsentrasi perlakuan. Adapun tingkat konsentrasi pemberian giberelin yaitu $\mathrm{G}_{0}(0 \mathrm{ppm}), \mathrm{G}_{1}\left(0,2 \mathrm{~g} \mathrm{~L}^{-1}\right.$ untuk mendapatkan $\left.200 \mathrm{ppm}\right)$, dan $\mathrm{G}_{2}$ $\left(0,4 \mathrm{~g} \mathrm{~L}^{-1}\right.$ untuk mendapatkan $\left.400 \mathrm{ppm}\right)$ kemudian diaplikasikan dengan cara disemprotkan pada bagian akar dan tunas tanaman. Pemberian giberelin dilakukan seminggu sekali yakni pada umur 2-11 MST.

\section{Pemeliharaann}

Kegiatan pemeliharaan terdiri dari penyiraman yang dilakukan pada pagi dan sore hari, penyiagan gulma, pengendalian hama dan penyakit yang dilakukan seminggu sekali. Hal ini bertujuan untuk mencegah serangan OPT (Organisme Pengganggu Tanaman). Pengendalian OPTdilakukandengan menggunakan insektisida dan fungisida dengan penyemprotan insectisida Decis 25 EC dan fungisida Dithane M-45 pada umru 2, 4,,6, 8 dan 10MST.

\section{Panen}

Dilakukan pemanenan pada saat bunga telah mekar sempurna. Bunga yang dipanen adalah bunga yang muncul dari setiap tanaman.

\section{Parameter Pengamatan}

Adapun parameter yang diamati dalam penelitian ini yaitu :

\section{Pertumbuhan}

\section{Jumlah cabang (tangkai)}

Semua jumlah cabang yang tumbuh pada batang dihitung dan dilakukan pengamatan seminggu sekali pada umur 30, 60 dan 90 HST.

\section{Panjang cabang (cm)}

Panjang cabang diukur mulai pangkal cabang sampai titik tumbuh dengan menggunakan metran. Pengamatan dilakukan seminggu sekali yaitu pada umur 30, 60 dan 90 HST. Jika cabang telah berbunga, panjang cabang diukur dari pangkal cabang sampai daun terakhir dari cabang.

\section{Diameter batag (mm)}

Pada bagian pangkal batang diukur dengan menggunakan jangka sorong dan dilakuakan pengamatan padaumur 30, 60 dan 90 HST.

\section{Hasil}




\section{Umur hari berbunga (minggu)}

Umur hari berbunga diamati dengan menghitung hari munculnya bunga pertama, dimulai dari penamanan hingga seluruh tanaman memunculkan bunga pertama.

\section{Diameter bunga (mm)}

Pengamatan diameter bunga dilakukan dengan cara mengukur bunga pertama setelah mekar sempurna dari sisi tepi terluar kuntum bunga mawar secara tegak lurus dengan menggunakan jangka sorong.

\section{Jumlh petal bunga (helai)}

Jumlah petal bunga dihitug dengan cara melepas semua petal atau mahkota bunga pertama satu per satu sambil dihitung jumlahnya.

\section{Jumlah bunga pertanaman}

Jumlah bunga pertanaman dihitung dengan cara menghitung semua jumlah bunga yang muncul pada tiap tanaman sampel dimulai dari awal penanaman hingga umur 12 MST. Bunga yang dihitung adalah bunga yang sudah mekar ataupun yang belum mekar (kuncup).

\section{HASIL DAN PEMBAHASAN}

\section{Pengaruh Media Tanam terhadap Pertumbuhan Tanaman Mawar}

Terlihat pada (Tabel 1) komposisi media tanam berpengaruh nyata terhadap jumlah cabang umur 30 HST namun berpengaruh tidak nyata terhadap parameter lainnya.

Tabel 1. Rata-rata pertumbuhan tanaman mawar akibat berbagai komposisi media tanam

\begin{tabular}{|c|c|c|c|c|c|c|}
\hline \multirow{2}{*}{\multicolumn{2}{|c|}{ Parameter yang diamati }} & \multicolumn{4}{|c|}{ Komposisi Media Tanam (1:1:1) } & \multirow{3}{*}{$\frac{\mathrm{BNT}_{0,05}}{-}$} \\
\hline & & \multirow{2}{*}{$\begin{array}{l}\left(\mathrm{M}_{0}\right) \\
22,41\end{array}$} & \multirow{2}{*}{$\begin{array}{l}\left(\mathrm{M}_{1}\right) \\
23,09\end{array}$} & \multirow{2}{*}{$\frac{\left(\mathrm{M}_{2}\right)}{22,81}$} & \multirow{2}{*}{$\frac{\left(\mathrm{M}_{3}\right)}{24,39}$} & \\
\hline Tinggi Tanaman $(\mathrm{cm})$ & $30 \mathrm{HST}$ & & & & & \\
\hline & $60 \mathrm{HST}$ & 22,52 & 23,93 & 23,31 & 24,67 & - \\
\hline & $90 \mathrm{HST}$ & 22,52 & 23,93 & 23,31 & 24,67 & - \\
\hline Jumlah Cabang (cabang) & $30 \mathrm{HST}$ & $1,41 \mathrm{a}$ & $1,85 \mathrm{~b}$ & $1,99 \mathrm{~b}$ & $1,67 \mathrm{~b}$ & 0,42 \\
\hline & $60 \mathrm{HST}$ & 2,44 & 3,63 & 2,85 & 2,48 & - \\
\hline & $90 \mathrm{HST}$ & 3,63 & 3,93 & 3,85 & 3,74 & - \\
\hline \multirow[t]{3}{*}{ Panjang Cabang (cm) } & $30 \mathrm{HST}$ & 3,19 & 3,89 & 3,61 & 3,65 & - \\
\hline & $60 \mathrm{HST}$ & 14,50 & 14,41 & 15,07 & 15,11 & - \\
\hline & $90 \mathrm{HST}$ & 18,20 & 18,67 & 19,31 & 19,06 & - \\
\hline Luas Daun $\left(\mathrm{cm}^{2}\right)$ & $90 \mathrm{HST}$ & 17,88 & 16,55 & 18,62 & 17,58 & - \\
\hline \multirow[t]{3}{*}{ Diameter Batang $(\mathrm{mm})$} & $30 \mathrm{HST}$ & 7,45 & 7,29 & 6,83 & 7,46 & - \\
\hline & $60 \mathrm{HST}$ & 8,14 & 7,87 & 7,47 & 8,19 & - \\
\hline & $90 \mathrm{HST}$ & 8,90 & 8,61 & 8,20 & 9,00 & - \\
\hline \multicolumn{2}{|c|}{ Umur Hari Berbunga (minggu) } & 6,89 & 7,41 & 7,41 & 7,28 & - \\
\hline
\end{tabular}




$\begin{array}{clllll}\text { Diameter Bunga (mm) } & 70,85 & 73,11 & 69,92 & 69,70 & - \\ \text { Jumlah Mahkota Bunga (helai) } & 24,00 & 24,89 & 23,74 & 22,78 & - \\ \text { Jumlah Bunga Pertanaman (tangkai) } & 3,00 & 2,89 & 2,89 & 2,89 & - \\ \text { Warna Bunga L (kecerahan) } & 62,33 & 46,52 & 45,00 & 48,19 & - \\ \text { a (merah) } & 69,41 & 68,59 & 66,67 & 71,26 & - \\ \text { b (kuning) } & 44,48 & 46,11 & 46,41 & 47,19 & -\end{array}$

Keterangan : Angka yang diikuti oleh huruf yang sama pada baris yang sama berbeda tidak nyata pada tara $5 \%\left(\mathrm{Uji} \mathrm{BNT}_{0,05}\right)$.

Pertumbuhan mawar terbaik dijumpai pada perlakuan $\mathrm{M}_{3}$ dibandingkan dengan perlakuan komposisi media tanam lainnya. Media tanam $\mathrm{M}_{3}$ merupakan media yang sesuai untuk pertumbuhan tanaman mawar. Hal ini diduga karena komposisi media tersebut menyebabkan tanah menjadi lembab tetapi tidak terlalu banyak mengikat air sehingga sesuai untuk pertumbuhan perakaran tanaman mawar. Menurut hasil penelitian yang telah dilakukan Susilawati (2007) penggunaan media tanah, sekam dan kompos pada tanaman Helichrysum bracteatum dan tanaman bunga kertas "Zinnia elegans" menyebabkan tinggi tanaman, diameter batang dan jumlah daun menjadi lebih baik.

Media yang mampu menyediakan air dan unsur hara dalam jumlah cukup bagi pertumbuhan suatu tanaman merupakan media tanam yang baik. Banyak jenis media tanam dapat digunakan, akan tetapi penggunaan media tanam harus mampu menyediakan nutrisi, air, dan oksigen bagi tanaman.

\section{Pengaruh Konsentrasi Giberlin terhadap Pertumbuhan Tanaman Mawar}

Terlihat pada (Tabel 2) konsentrasi giberelin berpengaruh sangat nyata terhadap panjang cabang umur 30 HST dan jumlah mahkota bunga seerta berpengaruh nyata terhadap jumlah cabang umur 30, 60 dan 90 HST.

Tabel 2. Rata-rata pertumbuhan tanaman mawar akibat berbagai konsentrasi giberelin

\begin{tabular}{|c|c|c|c|c|c|}
\hline \multirow{2}{*}{\multicolumn{2}{|c|}{ Parameter yang diamati }} & \multicolumn{3}{|c|}{ Konsentrasi Giberelin (ppm) } & \multirow{3}{*}{$\frac{\mathrm{BNT}_{0,05}}{-}$} \\
\hline & & \multirow{2}{*}{$\begin{array}{l}\left(\mathrm{G}_{0}\right) \\
22,60\end{array}$} & \multirow{2}{*}{$\begin{array}{l}\left(\mathrm{G}_{1}\right) \\
23,15\end{array}$} & \multirow{2}{*}{$\begin{array}{l}\left(\mathrm{G}_{2}\right) \\
24,50\end{array}$} & \\
\hline Tinggi Tanaman $(\mathrm{cm})$ & $30 \mathrm{HST}$ & & & & \\
\hline & $60 \mathrm{HST}$ & 22,89 & 23,15 & 24,78 & - \\
\hline & 90 HST & 22,89 & 22,43 & 24,78 & - \\
\hline Jumlah Cabang (cabang) & $30 \mathrm{HST}$ & $1,47 \mathrm{a}$ & $1,87 \mathrm{a}$ & $1,85 \mathrm{a}$ & 0,49 \\
\hline & $60 \mathrm{HST}$ & $2,59 \mathrm{a}$ & $2,60 \mathrm{a}$ & $2,79 \mathrm{a}$ & 0,54 \\
\hline & 90 HST & $3,33 \mathrm{a}$ & $3,73 \mathrm{ab}$ & $3,82 \mathrm{~b}$ & 0,43 \\
\hline \multirow[t]{3}{*}{ Panjang Cabang (cm) } & $30 \mathrm{HST}$ & $3,38 \mathrm{ab}$ & $2,97 \mathrm{a}$ & $4,40 \mathrm{c}$ & 1,01 \\
\hline & 60 HST & 15,03 & 14,22 & 15,07 & - \\
\hline & 90 HST & 18,85 & 18,86 & 18,72 & - \\
\hline Luas Daun $\left(\mathrm{cm}^{2}\right)$ & $90 \mathrm{HST}$ & 18,55 & 17,35 & 17,07 & - \\
\hline \multirow[t]{3}{*}{ Diameter Batang (mm) } & $30 \mathrm{HST}$ & 7,29 & 7,05 & 7,09 & - \\
\hline & $60 \mathrm{HST}$ & 7,93 & 7,71 & 7,74 & - \\
\hline & $90 \mathrm{HST}$ & 8,66 & 8,46 & 8,48 & - \\
\hline
\end{tabular}




$\begin{array}{clllc}\text { Umur Hari Berbunga (minggu) } & 7,17 & 7,31 & 7,26 & - \\ \text { Diameter Bunga (mm) } & 69,20 & 70,19 & 73,29 & - \\ \text { Jumlah Mahkota Bunga (helai) } & 21,64 \mathrm{a} & 24,97 \mathrm{~b} & 24,94 \mathrm{~b} & 2,96 \\ \text { Jumlah Bunga Pertanaman (tangkai) } & 2,89 & 2,97 & 2,97 & - \\ \text { Warna Bunga L (kecerahan) } & 46,06 & 58,33 & 47,14 & - \\ \quad \text { a (merah) } & 67,78 & 69,81 & 69,36 & - \\ \text { b (kuning) } & 46,19 & 44,97 & 46,97 & -\end{array}$

Keterangan : Angka yang diikuti oleh huruf yang sama pada baris ysng sama berbeda tidak nyata pada taraf $5 \%\left(\mathrm{Uji} \mathrm{BNT}_{0,05}\right)$.

Pemberian giberelin dengan konsentrasi 400 ppm merupakan konsentrasi terbaik untuk meningkatkan pertumbuhan dan pembungaan mawar. Hal ini diduga dengan pemberian giberelin pada konsentrasi 400 ppm dapat meningkatkan aktivitas fotosintesis, menstimulasi pembelahan sel dan pembesaran sel, sehingga pemberian giberelin dengan konsentrasi tersebut dapat merangsang pertumbuhan jaringan muda seperti tunas dan bunga. Sesuai dengan pernyataan Santoso dan Fatimah (2004) bahwa pemberian giberelin dapat mempengaruhi panjang batang, mendorong pembungaan, buah dan tumbuhnya mata tunas.

Hasil penelitian Rusmin (2007) menunjukkan bahwa pemberian $\mathrm{GA}_{3}$ dengan konsentrasi 400 ppm dengan lama imbibisi 48 jam dapat meningkatkan daya berkecambah, potensi tumbuh maksimum, indeks vigor, dan kecepatan perkecambahan benih purwoceng menjadi 1,5 -2 kali dibandingkan tanpa pemberian $\mathrm{GA}_{3}$. Konsentrasi giberelin yang diberikan dengan dosis yang tepat dapat membantu pertumbuhan dan pembungaan tanaman. Apabila konsentrasi yang diberikan pada tanaman tidak sesuai dengan dosis yang tepat maka akan menghambat pertumbuhan tanaman.

\section{Pengaruh Interaksi antara Komposisi Media Tanam dan Konsentrasi Giberlin tehadap Pertumbuhan Tanaman Mawar}

Terlihat pada (Tabel 3) terdapat interaksi yang nyata antara perlakuan komposisi media tanam dan konsentrasi giberelin terhadap diameter bunga tanaman mawar (Rosa hybrida L.)

Tabel 3. Rata-rata nilai interaksi antara perlakuan komposisi media tanam dan konsentrasi giberelin terhadap diameter bunga tanaman mawar (Rosa sp.)

\begin{tabular}{lcccc}
\hline \multirow{2}{*}{ Komposisi Media Tanam } & \multicolumn{3}{c}{ Konsentrasi Gibrelin $(\mathrm{ppm})$} & BNT \\
\cline { 2 - 4 } & $0\left(\mathrm{G}_{0}\right)$ & $200\left(\mathrm{G}_{1}\right)$ & $400\left(\mathrm{G}_{2}\right)$ & 0,05 \\
\hline tanah $\left(\mathrm{M}_{0}\right)$ & $70,94 \mathrm{aB}$ & $67,92 \mathrm{aAB}$ & $73,68 \mathrm{aA}$ & \\
tanah + pupuk kandang $\left(\mathrm{M}_{1}\right)$ & $70,62 \mathrm{aB}$ & $74,9 \mathrm{aB}$ & $73,76 \mathrm{aA}$ & \\
tanah + sekam $\left(\mathrm{M}_{2}\right)$ & $62,74 \mathrm{aA}$ & $73,90 \mathrm{bB}$ & $73,12 \mathrm{bA}$ & \\
tanah + pupuk kandang + sekam $\left(\mathrm{M}_{3}\right)$ & $72,50 \mathrm{bB}$ & $63,99 \mathrm{aA}$ & $72,60 \mathrm{bA}$ & \\
\hline
\end{tabular}


Keterangan: Angka-angka yang dikuti oleh huruf yang sama (huruf kecil horizontal (media tanam) dan huruf besar vertikal (giberelin)) menunjukkan tidak berbeda nyata pada uji $\mathrm{BNT}_{0,05}$

Diameter bunga pada tanaman mawar terbaik dijumpai pada kombinasi perlakuan komposisi media tanam $\mathrm{M}_{2}$ dan pemberian konsentrasi giberelin $200 \mathrm{ppm}\left(\mathrm{M}_{2} \mathrm{G}_{1}\right)$ walaupun secara statistik tidak berbeda nyata dengan kombinasi perlakuan komposisi media tanam $\mathrm{M}_{3}$ dan pemberian konsentrasi giberelin 0 ppm $\left(\mathrm{M}_{3} \mathrm{G}_{0}\right)$.

Media tanah + sekam merupakan media yang dapat meningkatkan diameter bunga tanaman mawar dengan pemberian konsentrasi giberelin 200 ppm yang tidak berbedanya nyata dengan penggunaan media $\mathrm{M}_{3}$ dengan pemberian konsentrasi giberelin $0 \mathrm{ppm}$. Hal ini dikarenakan media taman tanah + sekam memiliki kelebihan yaitu tidak mudah lapuk, tidak mudah menggumpal/memadat sehingga akar tanaman dapat tumbuh dengan sempurna. Pemberian giberelin dengan konsentrasi 200 ppm dapat merangsang perkembangan sel, terutama pada sel-sel muda. Hal ini didukung oleh hasil penelitian Zuhriyah (2004) bahwa pemberian giberelin dengan konsentrasi 200 ppm berpengaruh nyata terhadap tinggi tanaman dan perkembangan masa priomardia bunga, masa panen, diameter bunga, panjang tangkai bunga, jumlah daun dan luas daun pada tanaman krisan (Chrysanthemum indicum L.). Menurut Kusumawati et al. (2009) pemberian giberelin dengan konsentrasi 200 ppm dapat memacu pembungaan pada tanaman jarak pagar. Pertumbuhan dan pembungaan tanaman mawar terbaik menurut hasil penelitian Affriadi (2014) dijumpai pada pemberian giberelin dengan konsentrasi 200 ppm.

Penggunaan media tanam $\mathrm{M}_{3}$ dengan pemberian konsentrasi giberelin $0 \mathrm{ppm}$ $\left(\mathrm{M}_{1} \mathrm{G}_{0}\right)$ mampu memberikan hasil terbaik pada diameter bunga tanaman mawar yang tidak berbeda nyata dengan kombinasi perlakuan komposisi media tanam $\mathbf{M}_{2}$ dan pemberian konsentrasi giberelin $200 \mathrm{ppm}\left(\mathrm{M}_{2} \mathrm{G}_{1}\right)$. Hal ini dikarenakan media tanam $\mathrm{M}_{3}$ dapat memenuhi kebutuhan tanah dan juga dapat memperbaiki sifat fisik tanah yang akan mempermudah pertumbuhan dan perkembangan tanaman, sehingga media tersebut cocok dijadikan sebagai media tanam untuk meningkatkan diameter bunga tanaman mawar tanpa pemberian giberelin.

\section{KESIMPULAN DAN SARAN}

Dapat diambil kesimpulan berdasarkan hasil penelitian yang telah dilakukan bahwa media tanam berpengaruh nyata terhadap jumlah cabang tanaman mawar. Konsentrasi giberelin berpengaruh sangat nyata terhadap panjang cabang, jumlah mahkota bunga dan berpengaruh nyata terhadap jumlah cabang. Terdapat interaksi antara perlakuan komposisi media tanam dan konsentrasi giberelin berpengaruh nyata terhadap diameter bunga tanaman mawar pada kombinasi perlakuan komposisi media tanam tanah + sekam dengan pemberian konsentrasi 200 ppm. 


\section{DAFTAR PUSTAKA}

Dole, J.M. and H. F. Wilkins. 2005. Floriculture Principles and Species. Prentice Hall, Upper Saddle River. New Jersey. 161.

Zulkarnaen, 2006. Dasar-Dasar Hortikultura. Bumi Aksara, Jakarta.

Rukmana, R. 1995. Mawar. Kanisius, Yogyakarta.

Sulistyaningsih, L.N., Mutmainnah, M., dan Susilawati. 2007. Pengaruh campuran media tanam dan sitokinin terhadap pertumbuhan dan produksi bunga sedap malam (Polianthes tuberosa). Jurnal Agria. 4(1):1-6.

Budiarto K. dan Wuryaningsih S. 2007. Respon pembungaan beberapa kultivar Anthurium bunga potong. Agritop. 2(26):51-56.

Sumanasiri H., Krishnarajah S.A., and Eeswara J.P. 2013. Effect of Giberellic acid on growth and flowering of Henckelia humboldtianus gardner (Ceylon rock primrose). Wuryaningsih, S. dan D. Herlina. 2008. Pengaruh media dan pupuk terhadap pertumbuhan dan pembungaan mawar pot. Risalah Seminar Nasional Tanaman Hias : 44-51.

Susilawati, E. 2007. Pengaruh komposisi media tanam terhadap perkecambahan dan pertumbuhan tanaman Helichrysum bracteatum dan Zinnia elegans. Skripsi . Departeman Agronomi dan Hortikultura, Fakultas Pertanian. IPB, Bogor.

Santoso, U dan N. Fatimah. 2004. Kultur Jaringan Tanaman. UMM-Press, Malang.

Rusmin, D., F. C. Suwarno, dan I. Darwati. 2011. Pengaruh Pemberian GA 3 Pada Berbagai Konsentrasi dan Lama Imbibisi Terhadap Peningkatan Viabilitas Bnih Purwoceng (Pimpinella pruatjan Molk.). Jurnal Littri. 17-3:89-94.

Zuhriyah, D.T. 2004. Pengaruh konsentrasi giberelin $\left(\mathrm{GA}_{3}\right)$ dan pupuk daun terhadap pertumbuhan dan hasil tanaman krisan (Chrysantheum morifolium Ram). Tesis. Jurusan Agronomi Fakultas Pertanian Universitas Lampung, Lampung.

Kusumawati A, E. D. Hastuti dan N. Setiari. 2009. Pertumbuhan dan pembungaan tanaman jarak pagar setelah penyemprotan GA3 dengan konsentrasi dan frekuensi yang berbeda. Jurnal Penelitian dan Teknologi. 10(1):18-29.

Affriadi, F. 2014. Pengaruh kompos limbah bubuk kopi dan giberelin terhadap pertumbuhan dan pembungaan tanaman mawar. Skripsi. Program Studi Agroteknologi Fakultas Pertanian Universitas Syiah Kuala, Banca Aceh.

Wiryanata, B. T. W. 2007. Media Tanam untuk Tanaman Hias. Agromedia Pustaka, Jakarta. 
Endah, J.H. 2001. Membuat Tanaman Hias Rajin Berbunga. PT Agromedia Pustaka, Jakarta.

Cammpbell, N. A., Jane B. R., and Lauwrence G. M. 2003. Biologi Edisi Kelima. Jilid 2. Penerbit Erlangga, Jakarta.

Endah, J.H. 2001. Membuat Tanaman Hias Rajin Berbunga. PT Agromedia Pustaka, Jakarta.

Cammpbell, N. A., Jane B. R., and Lauwrence G. M. 2003. Biologi Edisi Kelima. Jilid 2. Penerbit Erlangga, Jakarta. 